\title{
İlkokulda gerçekçi matematik eğitimi ile gerçekleştirilen öğretimin öğrencilerin başarısına, görsel matematik okuryazarlığına ve problem çözme tutumlarına etkisi
}

\author{
The effet of instruction based realistic mathematics education on elementary \\ students' avhievement, visual mathematic literacy and problem solving attitude
}

\author{
Emel ÇILINGİR ALTINER* \\ Perihan Dinç ARTUT**
}

\begin{abstract}
Öz
$\mathrm{Bu}$ araştırmada ilkokulda gerçekçi matematik eğitimi ile gerçekleştirilen öğretimin öğrencilerin görsel matematik okuryazarlığına ve problem çözme becerilerine etkisini incelemek amaçlanmıştır. $\mathrm{Bu}$ amaçla bir devlet ilkokulunun dördüncü sınıfına devam eden 46 öğrencisi ile çalışılmıştır. Araştırmanın modeli karma desendir. Nicel kısmında, "Geometrik şekiller ve ölçme” konusu deney grubunda gerçekçi matematik eğitiminin gerektirdiği gibi işlenmesi, kontrol grubunda normal ders seyri devam ettirilmesi şeklinde oluşan öntest ve sontest kontrol gruplu yarı deneysel desen kullanılmıştır. Nitel kısmında ise görüşme tekniği kullanılmıştır. Veri toplama aracı olarak görsel matematik okuryazarlık algı ölçeği, problem çözmeye karşı tutum ölçeği, araştırmacılar tarafından hazırlanan başarı testi ön test ve son test ve görüşme formu kullanılmıştır. Çalışma 5 hafta sürmüştür. Nicel veriler Mann-Whitney U ve Wilcoxon Testleri ile nitel veriler özel durum analizi ile incelenmiştir. Analiz sonucunda deney grubundaki öğrencilerin kontrol grubundaki öğrencilere göre problem çözme başarıları bakımından daha fazla ilerlediği görülmüştür.
\end{abstract}

Anahtar Kelimeler: Gerçekçi Matematik Eğitimi, Görsel Matematik Okuryazarlığı, Problem Çözme

\footnotetext{
Abstract

The aim of this study was to investigate the effects of realistic mathematics education based instruction in the elementary mathematics curriculum of the fourth grade on the visual mathematics literacy self efficiency perceptions and problem-solving achievement. The research was conducted with 46 students at fourth grade of a public elementary school. The research has

* Arş. Gör.,Çukurova Üniversitesi, Eğitim Fakültesi, Temel Eğitim Bölümü, cilingire@gmail.com

** Prof. Dr., Çukurova Üniversitesi, Eğitim Fakültesi, Fen ve Matematik Eğitimi Bölümü, partut@cu.edu.tr
} 
a mixed-method design. In the quantitative part, one experimental and one control group were constituted with random assignment method. 'Geometric Shapes and Measurement' unit were instructed with realistic mathematics education at the experimental group while the current instructional method was followed at the control group. The quantitative data were supported by qualitative data gathered from interviews with participants. Data collection tools were obtained with Visual Mathematics Literacy Self Efficiency Perceptions Scale, Problem Solving Test developed by the researchers, Achievement Test prepared by researchers, pre-test and post-test and interview form. The implication process lasted seven weeks. After the implication procedures, all students at the experimental group were asked to answer seven questions of the structured interview form developed by the researchers. In order to analyze the quantitative data, MannWhitney $U$ and Wilcoxon Test were used whereas the qualitative data was analyzed with case study analysis. As a result, it was found that the students at the experimental group have more progress on problem-solving achievement than the students at the control group.

Keywords: Realistic Mathematics Education, Visual Mathematic Literacy, Problem Solving

\section{Giriş}

70’li yıllarda, masallar dünyasının ve günlük olayların çocuklara daha yakın olduğu ve bu olayların çocukların zihninde yeniden canlandırıldığı düşünüldüğünde soyut bir kavram olan matematiğin daha iyi anlaşılması adına yeni bir yaklaşım arayışına gidilmiştir. Bundan dolayı İngiltere, Almanya, Amerika Birleşik Devletleri, Japonya... gibi bir çok dünya ülkesi matematiğin günlük hayatta uygulanmasının önemli olduğunu vurgulayarak programlarını gözden geçirip, gerekli düzenlemeleri yapmışlardır. Farklı yaklaşımların ortaya konmasıyla birlikte diğer disiplinlerde olduğu gibi matematik ve matematik öğretiminde de öne çıkan uygulamalara yer verilmiş (“Avrupa’da Matematik Eğitimi”, 2011) ve geleneksel öğretime karşı gerçekçi matematik eğitimi (GME) yaklaşımı, matematik eğitimi alanına özgü bir öğretim kuramı olarak yapılandırılmıştır (Treffers, 1987; De Lange, 1987; Streefland, 1990, Gravemeijer, 1994; akt. Van den Heuvel-Panhuizen, 2003).

GME yaklaşımı "Matematiği aktarılan bir konu olarak görmek yerine bir insan aktivitesi olarak belirtilir (Freudenthal, 1977; akt. Van den Heuvel-Panhuizen, 2000)., matematik öğrenciye yakın olmalı, toplumla ilşkili olmalı ve gerçekle bağlantılı olmalıdır.” ana düşüncesinden yola çıkar ve problem durumları ortaya koyarak kişinin bunları çözmesini sağlar (Freudenthal, 1973). Asıl amaç, içinde bulunduğu durumda, yaşadığ 1 ortamda veya karşılaştığ 1 sorunda gizlenmiş matematiksel sürecin farkedilmesinin sağlanması ve matematiğe karşı olumlu tutum geliştirilmesidir, yani matematiğin her yerde olabileceğinin gösterilmesidir. GME yaklaşımına göre, öğrenciye sunulan problem durumları, öğrencinin anlamlı bir matematiksel etkinlik içinde yer almasının sağlanacağı, öğrencilerin bunları deneyimleştirebilecekleri ve gerçek yaşamda kullanıp uygulayabilecekleri tarzda olmalıdır (Ünal ve İpek, 2009). GME yaklaşımının en önemli ilkesi matematikleştirmedir. Treffers $(1978,2012)$ çalışmalarında matematikleştirmeyi ikiye ayırmıştır: "yatay" ve "dikey” matematikleştirme. Bu iki terim birbirinin devamı olarak 
anlaşlabilir. Yatay matematikleştirme, öğrencinin günlük yaşamındaki bir problemi çözmek ve düzenlemek için yardımcı olan matematiksel araçlara ulaşmasıdır. Dikey matematikleştirme, matematiksel sistemin içinde yeniden yapılanma sürecidir; örneğin, kavramlar ve stratejiler arasındaki kısayolları bulma, bağlantıları keşfetme ve daha sonra bu keşifleri uygulama. Yatay matematikleştirme gerçek yaşamdan semboller dünyasına geçişken, dikey matematikleştirme semboller dünyasında ilerlemedir. GME yaklaşımı biraz kafa karıştırıcı olarak görülebilir. Bunun nedeni "gerçekçi (realistic)" kelimesinin bu yaklaşımda farklı bir amaçla kullanılmasıdır. Buradaki "gerçekçi” kelimesi gerçek dünya ile bağlantının yanında öğrencilerin zihinlerindeki gerçek problem durumlarına işaret etmektedir (Demirdöğren ve Kaçar, 2010). Öğrencilere sorulan sorular gerçek yaşam dünyasından olacağı gibi fantastik masal dünyasından veya matematiğin formal dünyasından da olabilir (Van den Heuvel-Panhuizen, 2003). Materyaller, görsel skeçler, paradigmatik durumlar, şemalar, diyagramlar ve çoğu semboller GME yaklaşımında ders sürecinde kullanılabilir. Bu yüzden ders sürecinde öğrenciye yöneltilen problem cümleleri özenle ve amaca uygun bir şekilde seçilmelidir.

GME yaklaşımı ülkemizdeki eğitim programına yakın bir zamanda girmiştir. Birikimli olarak ilerleyen, değişen ve gelişen bilgiler ışığında eğitim programlarının güncelleştirilmesi ülkemizde de önem kazanmıştır. Artık ülkemizde de matematiği günlük hayata uygulayabilme, burada kullanabilme ve anlayabilme ihtiyacı önem kazanmıştır (MEB, 2009b). Bu anlamda, ilköğretimde matematik eğitimin genel amaçlarında bilgilerin günlük hayat problemlerine ve öğrenme alanlarına transfer edilmesi öne çıkmaktadır. Böylece öğretim programlarında yer alan GME ile birlikte hem program hem de öğretim, öğrenciler için günlük yaşamdan seçilen problemlerle, ikilemlerle ve sorularla başlaması önemli bir yer tutmaktadır.

Günlük yaşamdan seçilen problemlerin yanında bu problemlerin daha anlaşllır ve somut olması için görseller kullanılmaktadır. Görselleme, soyut düşüncelerin somutlaştırılması ya da resimlenmesi olarak, verilen görsel öğeler (resim, grafik vb.) yardımıyla, kavramların, görme duyusunun kolaylıkla algılayabileceği bir şekilde somutlaştırılması ve düzenlenmesi olarak, zihinde oluşturulan şekillerin ve uzamsal doğanın tüm temsillerinin matematik yapmak için oluşturulması ve dönüştürülmesi olarak tanımlanır (Gutierez, 1996). Sıradan bir yaşama uyum sağlayabilmek için bile görselleri okuyup anlama, analiz edip gerekli değerlendirmeleri yapma, kısaca "Görsel Okuryazar" olma ihtiyacı vardır. Görsel okuryazarlık diğer okuryazarlıkların hemen hemen hepsinin ya destekleyicisi ya da bir parçası olması açısından diğer disiplinlerle yakın ilişki içerisindedir (Kellner, 1998). Görsel okuryazarlık ile soyut düşünceleri canlı, inandırıcı ve bildik yaparak bireye onları daha iyi anlama olanağı sağlamasından ve aynı düşünceyi farklı yollarda işleme yeteneği kazandırmasından (İşler, 2002) dolayı matematik okuryazarlığı arasında daha güçlü bir ilişki vardır (Feinstein ve Hagerty, 1994; İpek, 2003). Matematiksel kavramların görselleştirilmesinin faydaları sıkça desteklenmesine rağmen, çoğu öğrenci bunu uygulamakta isteksizdir (Eisenberg ve Dreyfus, 1990). Bu durum "Görsel Matematik Okuryazarlık (GMOY)"1nı ortaya çıarmıştır. GMOY, gerçek hayatta karşımıza çıkan problemlerin görsel ve uzamsal özelliklerini matematiksel olarak algılama, ifade etme, yorumlama, uygulama ve değerlendirme yeterliği şeklinde tanımlanabilir (Duran ve Bekdemir, 2012). Dolayısıyla görsel matematik 
okuryazarlığı, karşılaşılan imgeleri oluştururken zihinsel faaliyetlerden yararlanma, kâğıt-kalem veya teknolojiden yardım alma ve bu imgelerin matematiksel bir keşif ya da anlama için kullanma süreci olarak da ifade edilebilir.

GME’de kullanılan materyallerin ve matematiksel sembollerin öğrencilerin zihinsel ve görsel aktivitelerini zenginleştireceği ve görsel okur-yazarlık algılarını değiştireceği ve bunu olumlu yönde etkileyeceği düşünülmektedir. Ancak öğrencilerin bu algılarını ölçen bir araştırmaya ulaşılabilen yerli ve yabancı rastlanmamıştır. Diğer araştırmalar incelendiğinde genel olarak GME yaklaşımının, problem çözme öğretimi (Verschaffel ve De Corte, 1997; De Corte, 2004), simetri öğretimi (Bintaş, Altun \& Arslan, 2003), kesirlerin öğretimi (Keijzer, 2003, Demirdöğen, 2008), sayı doğrusu öğretimi (Altun, 2002), akademik başarı (Ünal-Aydın, 2009; Demirdöğen, 2007), bir bilinmeyenli denklemlerin öğretimi (Üzel, 2007), açı kavramının öğretimi (Tunalı, 2010), sıvıları ve uzunlukları ölçmenin öğretimi (Can, 2012; Çakır, 2013), öğrencilerin yaratıcı düşünme süreçleri (Sitorus, 2016) üzerine etkileri araştırılmıştır. Hem görsel matematik okuryazarlığ̣ algılarını hem de geometrik şekiller ve ölçme konusunun öğretimini içerdiği için böyle bir çalışmanın yapılması önemli görülmüştür. Üst düzey becerilere ulaşmanın hedeflendiği matematik eğitiminde üzerinde çalışılan alternatif yaklaşımlar ışığında bu araştırma, ilkokulda Gerçekçi Matematik Eğitimi (GME) ile gerçekleştirilen öğretimin öğrencilerin başarısına, görsel matematik okuryazarlığ etkisini incelemeyi ve GME ile eğitim alan öğrencilerin bu yönteme ilişkin görüşlerini belirlemeyi amaçlamaktadır. Bu amaç doğrultusunda aşağıdaki sorulara yanıt aranacaktır.

a) GME yöntemi ile öğretim yapılan deney grubu ile mevcut yöntem ile öğretim yapılan kontrol grubu öğrencilerinin matematik başarıları arasında fark var mıdır?

b) Deney grubu ile kontrol grubu öğrencilerinin matematik problemlerini çözmeye yönelik tutumları arasında fark var midır?

c) Deney grubu ile kontrol grubu öğrencilerinin görsel matematik okuryazarlığı algıları arasinda fark var midır?

d) GME yönteminin uygulandığı öğrencilerin yönteme ilişkin görüşleri nasıldır?

\section{YÖNTEM}

İlkokulda Gerçekçi Matematik Eğitimi (GME) ile gerçekleştirilen öğretimin öğrencilerin başarısına, görsel matematik okuryazarlı̆̆ı algılarına ve matematik problemlerini çözmeye yönelik tutumlarına etkisini incelemeyi amaçlanan araştırmada karma desen kullanılmıştır. Karma yöntemin tercih edilmesinin sebebi tüm yöntemlerin ön yargı ve eksiklikler içermesi, nicel ve nitel verilerin birleşimi sayesinde her bir veri grubunun eksikliklerinin en az düzeye indirilebilmesidir (Creswell, 2016). Araştırmanın nicel boyutu öntest-sontest kontrol gruplu yarı deneysel bir çalışma olarak tasarlanmıştır Araştırma deney ve kontrol grupları oluşturularak, "geometrik şekiller ve ölçme" konusu bir sınıfta GME’nin gerektirdiği gibi işlenmesi kontrol grubunda normal ders seyri devam ettirilmesi şeklindedir. Araştırmanın nitel kısmında ise 
görüşme tekniği kullanılmıştır. Görüşme tekniği derinlemesine bilgi sağlanması bakımından avantajlı bir tekniktir. İnsanlardaki doğrudan gözlenemeyen, duygu, düşünce, niyet gibi davranışları belirlemek amacıyla görüşmeler yapılmaktadır (Patton, 2014).

\section{Çalışma grubu}

Araştırmanın çalışma grubunu gerekli izinleri alınmış olan Adana Yüreğir'deki bir ilkokulun 4. sınıfında okuyan 46 (24 kız, 22 erkek) öğrenci oluşturmaktadır. Başarı düzeyi birbirine yakın iki sınıf belirlenip deney (13 kız, 10 erkek) ve kontrol (11 kız ve 12 erkek) grupları rastgele oluşturulmuştur. Deney ve kontrol grubunun meydana getirilmesinde "yansız atama” yöntemi uygulanmıştır. Tablo l'de çalışma grubu gösterilmiştir.

Tablo I

Araştırmanın Çalışma Grubu

\begin{tabular}{lccccccc}
\hline Grup & & N & & & K & \multicolumn{2}{c}{ E } \\
& $\mathrm{f}$ & $\%$ & $\mathrm{f}$ & $\%$ & $\mathrm{f}$ & $\%$ \\
\hline Kontrol & 23 & 50 & 13 & 56.5 & 10 & 43.4 \\
Deney & 23 & 50 & 11 & 47.8 & 12 & 52.1 \\
Toplam & 46 & 100 & 24 & 52.1 & 22 & 47.8 \\
\hline
\end{tabular}

Tablo 1 incelendiğinde çalışma grubunun \%52.1’i kız, \%47.8’i erkek öğrenciden oluşmaktadır.

Veri toplama araçları

$\mathrm{Bu}$ araştırmada veri toplama aracı olarak, öğrencilerin Matematik Başarı Testi, Problem Çözmeye Yönelik Tutum Ölçeği ve Görsel Matematik Okuryazarlı̆̆ı Özyeterlik Alg1 Ölçeği kullanılmıştır. Nitel veriler ise yarı yapılandırılmış açık uçlu görüşme formları ile elde edilmiştir.

\section{Başarı testi}

Araştırmada TIMSS 2007 4. Sınıf matematik sorularından "geometrik şekiller ve ölçme" konusuna ait uluslar arası platformda geçerliği ve güvenirliği sağlanmış sorular kullanılmıştır. TIMSS 2007 sorularında özellikle görsel ögelerin kullanıldı̆̆ı, öğrencilerin günlük yaşamlarında da sıklıkla karşılarına çıkan ve öğrencilerin genel olarak yaşadığı kültüre de uygun olacağı düşünülen sorular seçilmiştir. İlkokul 4. Sınıfta okuyan ve farklı matematik başarısına sahip 9 öğrenci seçilerek Sorularda anlaşılmayan bir yer olup olmadığına dair bireysel görüşmeler yapılmıştır. Görüşmeler neticesinde düzenlenen 17 matematik sorusunun 7’si klasik, 11'i çoktan seçmelidir. Öğrenciler 100 puan üzerinden değerlendirilmiştir.

\section{Matematik Problemlerini Çözmeye Yönelik Tutum Ölçeği (MPÇYTÖ)}

Araştırmada Uğurluoğlu’nun (2008) geliştirdiği “Matematik Problemlerini Çözmeye Yönelik Tutum Ölçeği” kullanılmıştır. 272 öğrenciye uygulanan 27 maddenin 16’sı olumsuz ve 5’li likert 
tipi şeklindedir. Ölçek, 7. ve 8. sınıf öğrencilerine uygulanmıştır ve araştırmada bu ölçeğin 4 . sınıflara uygunluğunu test etmek için Doğrulayıcı Faktör Analizi (DFA) yöntemi kullanılmıştır. Araştırmacı tarafından ölçek 147 tane 4. sınıf öğrencisine uygulanmıştır. Tablo 2'de DFA modelinin uyum iyiliği indeksleri gösterilmiştir.

Tablo 2

MPÇYTÖ için DFA modelinin uyum iyiliği indeksi

\begin{tabular}{ccccccc}
\hline DFA Modeli & $\mathbf{N}$ & $\chi^{2}$ & sd & $\chi^{2} / \mathbf{s d}$ & SRMR & RMSEA \\
\hline MPÇYTÖ modeli & 147 & 558.79 & 323 & 1.73 & 0.07 & 0.07 \\
\hline Kabul edilebilir uyum & $\ldots$. & $\ldots$. & $\ldots$. & $\leq 3$ & $\leq 0.10$ & $\leq 0.10$ \\
\hline
\end{tabular}

Tablo 2'de görülen DFA modeline ilişkin uyum iyiliği indeksleri incelendiğinde SRMR (0.07) ve RMSEA (0.07)'nın kabul edilebilir uyumda olduğu, ki kare (558.79) değerinin iyi uyumda olduğu bulunmuştur. Bu sonuç doğrultusunda ölçeğin amacına yeterlik gösterdiği söylenebilir. Bu çalışmada araştırmacı, MPÇYTÖ’nin iç tutarlılığını belirlemek için hesaplanan Cronbach Alpha güvenirlik katsayısını 96 olarak bulmuştur. Bir ölçeğin güvenilir sayılabilmesi için literatürde kabul edilen katsayı .70 ve üzeridir (Tavşancıl, 2006). Bu bakış açısıyla ölçeğin güvenilir olduğu söylenebilir. Aynı zamanda ölçeğin iki yarısı arasındaki korelasyonun ölçeğin tamamını kapsaması için Spearman Brown testine göre katsayı 90 olarak bulunmuştur. Bu sonuç güvenirliğin onaylanmasını bir kez daha desteklemiştir.

\section{Görsel Matematik Okuryazarlığı Özyeterlik Algı Ölçeği (GMOÖA)}

Bu ölçek ilköğretim 7.sınıf öğrencilerinin GMOÖA puanlarını belirlemek amacıyla Duran ve Bekdemir (2011) tarafından geliştirilmiştir. 2'si olumsuz toplam 38 madde bulunmaktadır. Ölçekteki maddelerin 4. sınıf öğrencilerine ne derecede uyum gösterdiğini değerlendirmek amacıyla 147 öğrenciye DFA modeli uygulanmıştır. Tablo 3’te DFA modelinin uyu iyiliği indeksleri gösterilmiştir.

Tablo 3

GMOÖAÖ için DFA modelinin uyum iyiliği indeksi

\begin{tabular}{cccccccc}
\hline DFA Modeli & $\mathbf{N}$ & $\chi^{2}$ & sd & $\chi^{2} / \mathbf{s d}$ & SRMR & RMSEA & RMR \\
\hline GMOÖAÖ modeli & 147 & 1143.74 & 665 & 1.72 & 0.06 & 0.07 & 0.09 \\
\hline Kabul edilebilir uyum & $\ldots$ & $\ldots$ & $\ldots$ & $\leq 3$ & $\leq 0.10$ & $\leq 0.10$ & $\leq 0.10$ \\
\hline
\end{tabular}

Tablo 3'te yer alan DFA modeline ilişkin uyum iyiliği indeksleri incelendiğinde SRMR (0.06) ve RMSEA (0.07)'nın kabul edilebilir uyumda olduğu, ki kare (1143.74) değerinin iyi uyumda 
olduğu bulunmuştur. Bu sonuç doğrultusunda ölçeğin amacına yeterlik gösterdiği ve modelin doğrulandığ 1 söylenebilir. Duran ve Bekdemir (2011), hem ölçeğin hem de her bir faktörün iç tutarlık ölçütü olan Cronbach Alpha katsayısı 0.943 olarak bulmuşlardır. Bu çalışmada ise bu katsayı 0.946 olarak bulunmuştur. Spearman Brown iki yarı güvenirlik testinde katsayı 0.906 olarak bulunmuştur. Buradan yola çıkarak bulunan sonuçölçeğin güvenilir olduğunu göstermiştir.

\section{Görüşme formu}

Görüşme formunda deney grubundaki 20 öğrenciye sormak üzere, uzman görüşleri alınarak hazırlanmış 7 adet soru bulunmaktadır. GME hakkında öğrencilerin neler düşündükleri, bu yöntemi beğendikleri ve sıkıntı yaşadıkları bölümlerinin neler olduğu, GME doğrultusunda yapılan etkinliklere ve görsel materyallere yönelik görüşlerinin neler olduğu belirlenmeye çalışılmıştır. Bu sayede öğrencilerden GME yaklaşımı kullanılarak yapılan etkinliklerin değerlendirilmesi istenmiştir.

\section{Verilerin toplanması}

Verilerin toplanması aşamasında araştırmanın süreciyle ilgili bilgiler verilmiştir. Öncelikle araştırma için gerekli literatür taraması yapılmış, GME yaklaşımı ile ilgili uygulama örnekleri incelenmiş, hafta hafta ders planları şeklinde hazırlanmıştır. Ders planlarının içinde kazanımın adı, süresi, kullanılacak materyaller, sürecin nasıl yürütüleceği ve en sonunda da çalışma yaprakları bulunmaktadır. Bu sekiz adet ders planının uygunluğunun değerlendirilmesi için iki tane matematik öğretimi alanında uzman öğretim üyelerinin görüşü alınmıştır. Değerlendirme sonuçları incelenmiş ve gerekli düzenlemeler yapılmıştır. Nisan ayından itibaren daha önceden belirlenmiş ve MEB'den gerekli izinleri alınmış bir ilkokula gidilmiş, hazırlık çalışmalarından ve tanışma safhalarından sonra öntest uygulamalarına başlanmıştır. Öntestlerin uygulanmasının ardından, 4. sınıf “ geometrik şekiller ve ölçme” konusu iki farklı yöntem (deney grubuna GME yaklaşımı, kontrol grubuna ise mevcut yaklaşım) kullanılarak beş hafta boyunca matematik derslerinde işlenmiştir. GME yaklaşımının uygulandığı deney grubunda ders planları aracılığıyla, kontrol grubunda ise MEB’in öğrencilere dağıttığ ${ }_{1} 4$. sınıf matematik ders kitabı dikkate alınarak dersler işlenmiştir. Bu uygulamadan sonra sontestler uygulanmıştır. Uygulama sonuçlarından elde edilen verilerin, hangi analiz yöntemlerinin kullanılacağı hakkında uzman görüşleri alınarak, analizleri yapılmış ve daha sonra da bulgular değerlendirilmiştir.

\section{Veri analizi}

Uygulamanın analizi için SPSS 20.00 ve Excel programlarından yararlanılmıştır. Araştırmada kullanılan veriler sırasıyla şu analizlerden geçmiştir;

- Kayıp veri analizi

- İlişkisiz ölçümler için Mann Whitney U- Testi

- ̇̀lişkili ölçümler için Wilcoxon İşaretli Sıralar Testi

Çalışmada toplanan nitel verilerle ise betimsel analiz yöntemlerinden özel durum analizi yapılmıştır. Öğrencilerin doldurduğu görüşme formları öncelikle incelenmiş ve düzenli hale 
getirilmiştir. Sonra veriler kodlanmış ve temalara göre organize edilerek tanımlanmış, bulgular yorumlanarak analiz edilmiştir.

\section{BULGULAR}

Aşağıda araştırmanın denencelerine ilişkin bulguları ve yorumları irdelenmektedir.

\section{GME Yöntemi ve Mevcut Yöntem Ile Öğretim Yapılan Öğrencilerin Matematik Başarıları Arasında Fark Var mıdır?}

Deney ve kontrol grubundaki deneklerin öntest ve sontest olarak uygulanılan matematik başarısını belirlemeye yönelik testten aldıkları puanların aritmetik ortalamaları ve standart sapmaları hesaplanmış örneklem sayısı her bir grupta 30'dan az öğrenci olduğu için nonparametrik testlerden Mann Whitney U-Testi yapılmıştır. Deney ve kontrol gruplarının öntest ve sontestten aldıkları puanlara ilişkin bulgular Tablo 4’te verilmiştir.

Tablo 4.

Deney ve Kontrol Gruplarının Matematik Başarııını Ölçmeye Yönelik Öntest-Sontest Puanlarına Illişkin Bulgular

\begin{tabular}{ccccccc}
\hline & Grup & N & $\begin{array}{c}\text { Sıra } \\
\text { Ortalaması }\end{array}$ & $\begin{array}{c}\text { Sıra } \\
\text { Toplamı }\end{array}$ & U & p \\
\hline Öntest & deney & 23 & 23,52 & 541,00 & 264,00 & 0,991 \\
Başarı & kontrol & 23 & 23,48 & 540,00 & & \\
\hline Sontest & deney & 23 & 29,63 & 681,50 & 123,00 & $0,002^{*}$ \\
Başarı & kontrol & 23 & 17,37 & 399,50 & & \\
\hline
\end{tabular}

${ }^{*} \mathrm{p}<0,05$

Tablo 4’te görüldüğü gibi, matematik başarı testinin ön ölçümlerinde GME’nin uygulandığı deney grubunun sıra ortalamasının $(23,52)$ mevcut öğretim yöntemlerinin uygulandığı kontrol grubunun sıra ortalamasından $(23,48)$ yüksek olduğu görülmüştür. Aradaki farkın istatistiksel açıdan önemli olmadığı saptanmıştır $(U=264, p=0,991>0,05)$. Başka bir deyişle, deney ve kontrol gruplarının ön ölçümlerden elde edilen bulgularda deney ve kontrol gruplarındaki farklılık anlamlı bulunmamıştır.

Uygulama sonrasında deney grubundaki öğrencilerin sıra ortalamaları $(29,63)$ kontrol grubundaki öğrencilerin sıra ortalamalarından $(17,37)$ daha yüksek çıkmıştır. Deney grubu lehine olan 12,46 lık farkın anlamlı olup olmadığı Mann Whitney U- Testi ile sınanmış ve $(\mathrm{U}=123 ; \mathrm{p}=0,002<0,05)$ gruplar arasında istatistiksel açıdan anlamlı bir fark olduğu görülmüştür.

Sonuç olarak, elde edilen bulgular doğrultusunda GME yöntemi, öğrencilerin matematik başarı düzeylerini arttırmada, mevcut öğretim yöntemlerine göre daha etkili olduğu söylenebilir. 
Süreç içerisinde deney ve kontrol gruplarındaki öğrencilerin Matematik başarı düzeylerinin grup içi değişimi de incelenmiştir. İlk olarak deney grubunda öğrencilerin Matematik Başarı düzeylerine ait öntest ve sontest puanlarına arasında önemli farklılık oluşup oluşmadığ belirlenmek istenmiştir. Bu amaçla yine nonparametrik testlerden Wilcoxon İşaretli Sıralar Testi yapılmıştır. Sonuçlar Tablo 5’te verilmiştir.

\section{Tablo 5.}

Deney ve Kontrol Grubundaki Öğrencilerin Matematik Başarı Düzeylerine Ait Öntest-Sontest Puanlarina Ilişkin Wilcoxon Testi

\begin{tabular}{ccccccc}
\hline \multicolumn{2}{c}{ Öntest-sontest MPÇYT } & N & $\begin{array}{c}\text { Sıra } \\
\text { Ortalaması }\end{array}$ & Sıra Toplamı & z & p \\
\hline \multirow{2}{*}{$\begin{array}{c}\text { Deney } \\
\text { Grubu }\end{array}$} & Negatif Sıralar & 1 & 4,00 & 4,00 & $-4,091^{*}$ & $0,000^{*}$ \\
& Pozitif Sıralar & 22 & 12,36 & 272,00 & & \\
\hline \multirow{2}{*}{$\begin{array}{c}\text { Kontrol } \\
\text { grubu }\end{array}$} & Negatif Sıralar & 7 & 12,07 & 84,50 &,$- 044^{*}$ & 0,965 \\
\hline
\end{tabular}

Negatif sıralar temeline dayanmaktadır

${ }^{*} \mathrm{p}<0,05$

Tablo 2'de görüldüğü gibi deney grubu öntest-sontestten aldıkları puanların sıra ortalaması ve toplamları arasında istatistiksel olarak anlamlı bir farklılık olduğu görülmektedir. Bu farkın sontest puanları lehine olduğu gözlenmektedir $(\mathrm{z}=4,091 ; \mathrm{p}=.00<0,05)$. Bulguya göre GME yönteminin öğrencilerin Matematik Başarı düzeylerini arttırmada etkisinin olduğu söylenebilir.

Kontrol grubundaki öğrencilerin matematik başarı düzeylerine ait öntest ve sontest puanlarını karşılaştırmak için yapılan testin sonuçlarına göre kontrol grubundaki öğrencilerin matematik başarı düzeylerine ait öntest-sontest puanların sıra ortalaması ve toplamları arasında istatistiksel olarak anlamlı düzeyde bir farklılık yoktur $(\mathrm{z}=1,874 ; \mathrm{p}>0,05)$.

Araştırmanın bu aşamasında elde edilen bulgular genel olarak incelendiğinde, deney grubundaki öğrencilerin matematik başarı düzeylerinde kontrol grubundaki öğrencilerinkine göre öntest ve sontest sonuçlarında anlamlı fark oluşturduğu görülmektedir.

GME Yöntemi ve Mevcut Yöntem Ile Öğretim Yapılan Öğrencilerin Matematik Problemlerini Çözmeye Yönelik Tutumları (MPÇYT)Arasında Fark Var mıdır?

Problem durumunu incelemek için deney ve kontrol gruplarında yer alan öğrencilerin Geometrik Şekiller ve Ölçme” konusunda öntest-sontest MPÇYT’lerini belirlemek için aradaki fark Mann-Whitney U-Testi ile analiz edilmiştir. Deney ve kontrol gruplarının öntestten aldıkları puanların analizi Tablo 6'da verilmiştir. 


\section{Tablo 6}

Deney ve Kontrol Gruplarının MPÇYT'lerinin Öntest- Sontest Puanlarına Illişkin Bulgular

\begin{tabular}{ccccccc}
\hline & Grup & $\mathbf{N}$ & $\begin{array}{c}\text { Sira } \\
\text { Ortalaması }\end{array}$ & $\begin{array}{c}\text { Sira } \\
\text { Toplamı }\end{array}$ & U & p \\
\hline Öntest & deney & 23 & 22,00 & 506,00 & 237,500 & 0,553 \\
MPÇYT & kontrol & 23 & 25,00 & 575,00 & &, $0008^{\star}$ \\
\hline Sontest & deney & 23 & 28,17 & 648,00 & 157,000 & \\
MPÇYT & kontrol & 23 & 18,83 & 433,00 & & \\
\hline
\end{tabular}

${ }^{*} \mathrm{p}<0,05$

Tablo 6'ya göre, MPÇYT'yi belirleyen ölçme aracından kontrol grubundaki öğrencilerin sıra ortalamalarının $(22,00)$ deney grubundakilerin sıra ortalamalarından $(25,00)$ düşük olduğu görülmüştür. Aradaki farkın istatistiksel açıdan önemli olmadığı saptanmıştır ( $U=237,5, p>0,05)$. Bu bulguya dayanarak, deneysel çalışma öncesinde deney grubu ile kontrol grubu öğrencilerinin MPÇYT’lerinin hemen hemen denk olduğu ifade edilebilir.

Deneysel çalışmanın etkililiğini gözlemek amacıyla deney ve kontrol gruplarında MPÇYT'lerinin sontest puanlarının farklılaşıp farklılaşmadığına bakılmış ve deney ve kontrol gruplarındaki öğrencilerin MPÇYT ölçeğinden aldıkları sontest puanları arasında anlamlı fark görülmüştür $(U=157 ; \mathrm{p}<0,05)$. Bu farklılık deney grubu lehine olduğu söylenebilir.

Sonuçta deney ve kontrol grubundaki öğrencilerin MPÇYT’leri üzerindeki farklılı̆̆ın anlamlı olduğu gözlenmiştir. $\mathrm{Bu}$ durum, uygulamadan sonra deney grubundaki öğrencilerin tutum düzeylerini arttırdığ

Deney ve kontrol gruplarının süreç içerisinde MPÇYT’lerinin grup içi değişimi de incelenmiştir. Öncelikle deney grubundaki öğrencilerin öntest-sontest MPÇYT’lerini belirlemek için yapılan Wilcoxon Testi’nin sonuçları Tablo 7’de görülmektedir.

Tablo 7

Deney ve Kontrol Grubundaki Öğrencilerin MPÇYT'lerine Ait Öntest-Sontest Puanlarına Ilişkin Wilcoxon Testi

\begin{tabular}{ccccccc}
\hline \multicolumn{2}{c}{ Öntest-sontest MPÇYT } & N & $\begin{array}{c}\text { Sıra } \\
\text { Ortalaması }\end{array}$ & $\begin{array}{c}\text { Sıra } \\
\text { Toplamı }\end{array}$ & z & p \\
\hline \multirow{2}{*}{$\begin{array}{c}\text { Deney } \\
\text { Grubu }\end{array}$} & $\begin{array}{c}\text { Negatif } \\
\text { Sıralar }\end{array}$ & 0 &, 00 &, 00 & $-4,202^{*}$ & $0,000^{*}$ \\
& $\begin{array}{c}\text { Pozitif } \\
\text { Sıralar } \\
\text { Eşit }\end{array}$ & 23 & 12,00 & 276,00 & & \\
& Negatif & 0 & & & & \\
\hline \multirow{2}{*}{$\begin{array}{c}\text { Kontrol } \\
\text { grubu }\end{array}$} & $\begin{array}{c}\text { Sıralar } \\
\text { Pozitif }\end{array}$ & 11 & 12,07 & 84,50 &,$- 044^{*}$ & 0,965 \\
& $\begin{array}{c}\text { Sıralar } \\
\text { Eşit }\end{array}$ & 5 & 7,86 & 86,50 & & \\
& & & & & & \\
\hline
\end{tabular}

Negatif sıralar temeline dayanmaktadır

$$
{ }^{*} \mathrm{p}<0,05
$$


Tablo 7’de görüldüğü gibi deney grubu öğrencilerinin öntest-sontest MPÇYTÖ’den aldıkları puanların sıra ortalaması ve toplamları arasında anlamlı bir farklılık olduğu görülmektedir. Gözlenen fark son test puanları lehinedir $(\mathrm{z}=4,202 ; \mathrm{p}=.0,00<0,05)$. Bu bulguya göre GME yönteminin öğrencilerin MPÇYT’leriniolumlu olarak arttırmada etkisinin olduğu söylenebilir.

Kontrol grubundaki örgencilerin MPÇYT’lerine ait ön test ve son test puanlarını karşılaştırmak için yapılan testin sonuçlarına göre kontrol grubundaki öğrencilerin MPÇYT’lerine aitön testsontest puanların sıra ortalaması ve toplamları arasında anlamlı düzeyde farklılık yoktur $(\mathrm{z}=0,044$; p>0,05). Yani kontrol grubundaki öğrencilerin MPÇYT düzeylerinde önemli bir artış olmamıştır.

Sonuç olarak, araştırmada MPÇYT ile ilgili elde edilen bulgular incelendiğinde, deney grubundaki öğrencilerin MPÇYT’lerinde kontrol grubundaki öğrencilerinkine göre öntestsontest sonuçları doğrultusunda anlamlı bir fark oluşturduğu görülmektedir.

GME Yöntemi Ve Mevcut Yöntem Ile Öğretim Yapılan Öğrencilerin Görsel Matematik Okuryazarlığı Özyeterlik Algıları (GMOÖA) Arasında Fark Var mıdır?

Deney ve kontrol gruplarında yer alan öğrencilerin "Geometrik şekiller ve Ölçme” konusuna başlamadan önce ve başladıktan sonra GMOÖA’larının farklılaşıp farklılaşmadığına bakılmıştır. Öğrencilerin testlerden aldıkları puanlara göre sıra ortalamaları ve sıra toplamları belirlenmiştir. Öğrencilerin GMOÖA arasındaki fark Mann-Whitney U-Testi ile sınanmış ve bulgular Tablo 8'de verilmiştir.

\section{Tablo 8}

Deney ve Kontrol Gruplarının GMOÖAÖ Öntest-Sontest Puanlarına Illişkin Bulgular

\begin{tabular}{ccccccc}
\hline & Grup & $\mathbf{N}$ & $\begin{array}{c}\text { Sira } \\
\text { Ortalaması }\end{array}$ & $\begin{array}{c}\text { Sira } \\
\text { Toplamı }\end{array}$ & U & p \\
\hline Öntest & deney & 23 & 19,46 & 447,50 & 171,50 & $0,041^{*}$ \\
GMOÖA & kontrol & 23 & 27,54 & 633,50 & & \\
\hline Sontest & deney & 23 & 23,76 & 546,50 & 258,5 & 0,895 \\
GMOÖA & kontrol & 23 & 23,24 & 534,50 & & \\
\hline
\end{tabular}

${ }^{*} \mathrm{p}<0,05$

Tablo 8'den, deney ve kontrol gruplarındaki öğrencilerin GMOÖAÖ öntest puanları arasında anlamlı fark olduğu anlaşılmaktadır $(\mathrm{U}=171,5 ; \mathrm{p}<0,05)$. Bu bulgu uygulama öncesi deney ve kontrol gruplarındaki öğrencilerin GMOÖA’larının birbirinden farklı olduğunu göstermektedir. Kontrol grubunun sira ortalamasinın $(27,54)$, deney grubu sira ortalamasindan $(19,46)$ fazla olduğu görülmektedir.

Deney ve kontrol grubu öğrencilerinin GMOÖA’larına ait sontest puanları arasındaki farkın anlamlı olup olmadığına bakılmıştır. Öğrencilerin GMOÖA’larına ait son test puanları arasında sıra ortalaması ve sıra toplamına göre anlamlı bir fark olmadığı saptanmıştır ( $U=258,5 ; \mathrm{p}>0,05)$. 
Araştırma kapsamında deney ve kontrol gruplarındaki öğrencilerin süreç içerisinde GMOÖA’larının değişip değişmediğine de bakılmıştır. Deney grubundaki öğrencilere ilişkin sonuçlar Tablo 9'da özetlenmiştir.

Tablo 9

Deney Grubundaki Öğrencilerin GMOÖAÖ'lerine Ait Öntest-Sontest Puanlarına Illişkin Wilcoxon Testi

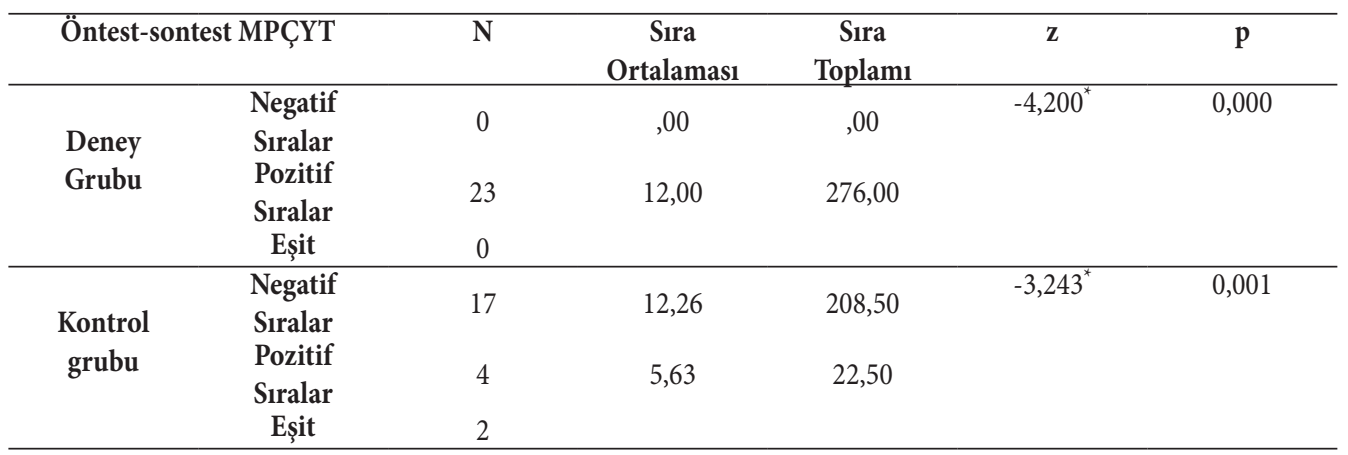

Negatif sıralar temeline dayanmaktadır

${ }^{*} \mathrm{p}<0,05$

Tablo 6 incelendiğinde, deney grubunun GMOÖAÖ’larının öntest-sontest puanlarına göre $(\mathrm{z}=4,2 ; \mathrm{p}<0,05)$ gözlenen fark son test puanlar lehine olduğu görülmüştür. Sonuç olarak GME yöntemi öğrencilerin GMOÖA’larını olumlu yönde etkilemiştir.

Kontrol grubundaki öğrencilerin GMOÖA’larının ön test ve son test puanları karşılaştırılmak istenmiştir. Kontrol grubundaki öğrencilerin GMOÖA'larına ait öntest-sontest puanların sıra ortalaması ve toplamları arasında anlamlı düzeyde farklılık vardır $(z=3,243 ; p<0,05)$.

Elde edilen bulgular incelendiğinde, her iki yöntemin de öğrencilerin GMOÖA’larında ön test ve son test sonuçları doğrultusunda anlamlı bir fark oluşturduğu görülmektedir.

\section{GME Yönteminin Uygulandığı Öğrencilerin Yönteme Ilişkin Görüşleri Nasıldır?}

'Geometrik şekiller ve ölçme’ konusunun GME yaklaşımı ile öğretimi sonunda deney grubundan gönüllülük esas alınarak 20 öğrenciye dağıtılan görüşme formlarından elde edilen bulgulara yer verilmiştir.

\section{Sınıf Ortamına Yönelik Görüşler}

Sınıf ortamı açısından elde edilen görüşlerin değerlendirilmesi şöyledir: sınıfın matematik etkinlikleriyle ve işaretleriyle dolu olması öğrencileri derse motive etmiştir. Öğrencilerin grup çalışması yapacak şekilde sıraları düzenlenmiş ve bu da derse olan ilgiyi arttırmıştır. Grupla çalışmaya alışık olmayan öğrenciler kendi aralarında tartışmalara girmiş bu da sınıfta gürültünün oluşmasına neden olmuştur. Öğrencilerin görüşleri incelendiğinde sınıf ortamı ile ilgili genel durum Tablo 10'da ortaya konduğu gibi görülmektedir. 
Tablo 10

Sınıf Ortamına Yönelik Görüşler

\begin{tabular}{lccc}
\hline & Görüssler & f & \% \\
\hline Sessiz bir sınıf olmalı & 8 & 47,05 \\
Her yerin matematiksel mateyallerle kaplı olması & 4 & 23,52 \\
Her yerin etkinliklerle dolu olması & 3 & 17,64 \\
Herkesin eğlenmesi & 3 & 17,64 \\
Toplam & 17 & 100 \\
\hline
\end{tabular}

Tablo 10 incelendiğinde sınıf ortamına yönelik farklı görüşlerin ortaya çıktığı söylenebilir. $\mathrm{Bu}$ durum öğrencilerin bireysel farklılıklarından kaynaklandığı düşünülmektedir. Farklı zeka yapısına sahip öğrenciler için sınıf ortamında sessiz olmaması odaklanma sorunu yaşanmasına sebep olmuş olabilir.

Ö1:"Sınıf ortamı daha sessiz olmalı, sadece öğretmen dinlenilmeli, parmak kaldırılarak konuşulmalı."

Ö8: "Her tarafta matematik işaretlerinin olmasını istiyorum."

Ö12: "Derste herkes eğleniyor ve akıllı duruyor."

\section{Dersin İşlenişine Yönelik Görüş̧ler}

Öğrenciye yönelik aktiviteler hazırlanmış ve grup çalışmaları yoluyla öğrencilerin eğlenerek, ihtiyaç hissederek düşünmeleri etkinlikler yoluyla sağlanmaya çalışılmıştır. Bunun sonucunda öğrencilerin matematik dersinde dersin işlenişine göre görüssleri genel olarak Tablo 11'de gösterilmiştir.

\section{Tablo II}

Dersin İslenişine Yönelik Görüşler

\begin{tabular}{|c|c|c|}
\hline Görüşler & $\mathrm{f}$ & $\%$ \\
\hline Eğlenerek öğrendim & 10 & 34,48 \\
\hline Derste ölçüm yapmayı çok sevdim & 4 & 13,79 \\
\hline Problemleri çok sevdim & 4 & 13,79 \\
\hline Derste dans etmeyi çok sevdim & 3 & 10,34 \\
\hline Simetri dersini çok sevdim & 2 & 6,89 \\
\hline Matematikle oyun oynadik & 2 & 6,89 \\
\hline Derste her zaman posterler yapmak isterim & 1 & 3,44 \\
\hline Hayvanat bahçesini çok sevdim & 1 & 3,44 \\
\hline Futbolda bile açı varmış, o yüzden ilgimi çekiyor & 1 & 3,44 \\
\hline Dans etmeyi hiç sevmedim & 1 & 3,44 \\
\hline Toplam & 29 & 100 \\
\hline
\end{tabular}


Tablo 11'e göre öğrencilerin görüşleri incelendiğinde ders sürecinde eğlenerek dersi öğrendikleri görülmektedir. Yapılan uygulamaların ezberin önüne geçtiği ve öğrencilerin bunları neden öğrendiklerini anladıkları söylenebilir. Genel olarak öğrencilerin yorumları dikkate alındığında matematiği şuan ve gelecekte kullanabileceklerini fark ettiklerinin bir göstergesi olabilir.

Ö5: "Matematiği sevmesem bile öğretmen derste eğlenceli şeyler yaptırıyor.”

Ö9: “Gelecekte işime yarayacak şeyler öğreniyorum. Futbol oynarken bile açıyı kullanıyorum”

\section{Matematik ve Günlük Hayata Yönelik Görüşleri}

GME’nin omurgası olan matematiğin günlük hayatla ilişkilendirilmesi süreç boyunca sürekli vurgulanmıştır. Öğrencilerin matematiği günlük yaşamlarında kullanabilmesi için onu ihtiyaç hissetmelerini sağlayacak problemlerle derse giriş yapılmıştır. Öğrencilerin matematik ve günlük hayata yönelik görüşleri adlı tema Tablo 12'de gösterilmiştir.

Tablo 12

Matematik ve Günlük Hayata Yönelik Görüşleri

\begin{tabular}{|c|c|c|}
\hline Görüşler & $\mathrm{f}$ & $\%$ \\
\hline Alışveriş yaparken bize yardımcı olur & 3 & 25 \\
\hline Değişik mesleklerde kullanılır & 2 & 16,66 \\
\hline Her gün yeni bir şeyler öğreniyoruz & 1 & 8,33 \\
\hline Resim yaparken bile matematiği kullanıyorum & 1 & 8,33 \\
\hline Günlük hayatta her şey için matematik önemli & 1 & 8,33 \\
\hline Bir şeyin alanını ve çevresini ölçerken ne yapmam gerektiğini artık biliyorum & 1 & 8,33 \\
\hline Günlük problemlerimi anlamam ve çözmeme yardımcı oluyor & 1 & 8,33 \\
\hline Hayatımı kolaylaştırıyor & 1 & 8,33 \\
\hline Matematik yararlı işler için kullanılıyor & 1 & 8,33 \\
\hline Toplam & 12 & 100 \\
\hline
\end{tabular}

Tablo 12'ye göre derste yapılan etkinlikler sayesinde günlük hayatta karşılaştığı problemlere nasıl çözüm üretecekleri hakkında alternatif fikirler üretmelerinde matematiğin etkisinin farkına vardıkları söylenebilir. Matematiğin tek dersten ibaret olmayıp hayatlarını kolaylaştırmada da işe yaradığını etkinlikler sayesinde keşfetmişlerdir.

Matematik dersinin günlük hayatta sağladığı yararlara ilişkin öğrenci görüşleri şöyledir:

Ö13: "Her gün bir şeyler öğreniyoruz, bunları her yerde kullanabilirim.”

Ö15: "Değişik mesleklerde istediğimiz şeyleri yapabiliriz. İlerde mimar olacağım, evin krokisini çizerken lazım olacak" 


\section{Matematik ve Görselliğe Yönelik Görüşleri}

GME’ye dayalı yapılan dersteki etkinlikler ile görsel materyallere ve günlük hayat durumlarına sık başvurulmaktadır. Görselleştirerek öğrenmenin dersi daha zevkli kıldığı öğrenciler tarafından belirtilmektedir. Tablo 13’te matematik ve görselliğe yönelik görüşler yer almaktadır.

Tablo 13

Matematik ve Görselliğe Yönelik Görüşler

\begin{tabular}{lccc}
\hline & Görüsşler & f & $\%$ \\
\hline Görsel & & 15 & 93,75 \\
Hem görsel hem sözel & 1 & 6,25 \\
Toplam & 16 & 100 \\
\hline
\end{tabular}

Tablo 13 incelendiğinde öğrencilerin görsel problemlerin sözel problemlere göre daha çok tercih edildiği görülmektedir. Bunun sebebi olarak ise öğrenciler görsel problemler olunca daha az karıştıracaklarını, uzun soruların kafa karıştırıldığını, bu şekilde daha anlaşılır ve eğlenceli olduğunu belirtmişlerdir. Öğrenciler bu uzun görsellerle desteklenmiş problemleri sevdiklerini belirtmişlerdir.

Ö2: "Görsel olarak verilen problemleri daha çok seviyorum çünkü böyle karıştırmayız."

Ö11:"Görsel problemleri daha iyi anliyorum."

\section{TARTIŞMA VE SONUÇ}

Ulaşılan bulgulara ilişkin tartışma ve yorumlar bu bölümde sunulmuştur.

Araştırmada ilk olarak öğrencilerin matematik başarıları test edilmiş ardından elde edilen veriler SPSS programına girilerek analizleri yapılmıştır. Analiz sonucunda GME yönteminin uygulandığı deney grubu öğrencilerinin ve mevcut yöntemin uygulandığı kontrol grubu öğrencilerinin ön test puanları ortalamaları karşılaştırıldığında aralarında anlamlı farklılığın olmadığı görülmüştür.

GME ile öğretim alan deney grubu öğrencilerinin akademik başarı son test puan ortalaması ile mevcut yöntemle öğretim alan kontrol grubu öğrencilerinin son test başarı ortalamaları arasında anlamlı bir farklılığın olduğu görülmüştür. Bu sonuçtan yola çıkılarak GME yaklaşımının öğrencilerin akademik başarılarını arttırmada olumlu yönde bir etkisinin olduğu söylenebilir.

Alan yazın incelendiğinde GME yaklaşımının farklı matematik konuları üzerinde uygulandığı çalışmalarda (Wubbels, Korthagen \& Broekman, 1997; Bintaş vd., 2002; Fauzan, Slettenhaar \& Plomp, 2002; Kwon, 2002; Widjaja, 2002; Zulkardi, 2002; Van Reeuwijk, 2004; Talati, 2004; De Corte, 2004; Eade \& Dickinson, 2006; Demirdöğen, 2007; Fyhn, 2008; Ünal-Aydın, 2009, 
akt. Çilingir, 2015) bu çalışmanın sonucunu da destekler nitelikte başarılı sonuçlar elde edildiği görülmektedir.

Gerçekleştirilen uygulamada GME yaklaşımının öğrencilerin MPÇYT’leri üzerinde istatistiksel olarak anlamlı bir farklılığın olduğu görülmüştür. Araştırma sonucunda elde edilen deney grubundaki öğrencilerin MPÇYT’lerindeki bu artış GME yaklaşımının olumlu etkisini gösterdiği şeklinde ifade edilebilir. Verschaffel ve De Corte (1997), De Corte (2004) GME yaklaşımını kullanarak problem çözmenin öğretiminde kalıcı öğrenmeyi sağladıkları ortaya çıkmıştır. Bu yaklaşım sayesinde öğrencileri matatematik problemlerini çözmeye karşı olumlu tutum geliştirdikleri söylenebilir. Bu da araştırmadan elde edilen bulgularla paralellik göstermektedir. Literatürde bu bulguları destekleyen başka araştırmalar da bulunmaktadır. Bu araştırmalar şöyledir: Verschaffel vd. (1999), Keller (1990) yaptıkları çalışmalarda öğrenme ortamından zevk alan öğrencilerin matematik dersinde problem çözmeye karşı daha olumlu tutum geliştirdikleri sonucuna ulaşmışlardır. GME'de de öğrencinin günlük yaşam problemlerini çözerken zevk alacakları ve eğlenceli öğrenme ortamlarının sağlandığı düşünülecek olursa bu durumun araştırma bulgumuzu desteklediği söylenebilir (akt. Çilingir, 2015).

$\mathrm{Bu}$ çalışmada aynı zamanda, deney grubundaki öğrencilerin GMOÖA diğer gruba göre daha yüksek oranda yükselme meydana geldiği görülmüştür. Ancak her iki grupta da kendi içinde ön test-son test puanları arasında anlamlı farklılık gözlenmiştir. Literatür incelendiğinde GMOY ile ilgili çok fazla kaynak bulunmamaktadır. Mevcut bulunan birkaç kaynağa göre, Duran ve Bekdemir (2013) çalışmalarında GMOYÖA ile görsel matematik başarısı arasında orta düzeyde, olumlu ve anlamlı bir ilişki olduğunu belirtmişler ve çalışmalarında görsel matematik okuryazarlığı özyeterlik algıları yüksel olan öğrencilerin görsel akademik başarılarının da yüksek olduğunu ortaya çıkarmışlardır. Bu sonuç araştırma bulgularını destekler niteliktedir. Ayrıca GMOYÖA, görsel matematik başarısının anlamlı bir şekilde açıllayabilir. Analizler sonucunda 'görsel matematik okuryazarı olmanın görsel matematik başarısını arttıracağı' görüşü (Duran, 2016) araştırmanın bulgularıyla desteklenmiştir. NCTM (1989)'de de matematik okuryazarı olan çocukların hem matematiğe karşı olumlu tutum geliştirdiği hem de problem çözme becerilerinin çok iyi olduğu belirtilmiştir. Görsel ögeler ve günlük yaşamın içinden örneklerle zenginleştirilmiş etkinliklerin bulunduğu GME yaklaşımı ile hem akademik başarıyı arttırması, hem de görsel matematik okuryazarlık algılarının ve problem çözmeye yönelik tutumlarının deney grubu lehine farklılaştırması neticesinde bu yaklaşımın etkin bir şekilde kullanılması gerektiğini düşündürmektedir.

Araştırmanın sınırlılıklarından biri yeterli sayıda GMOYÖA ile ilgili çalışmanın bulunmamasıdır. Daha fazla sayıda çalışma yapılarak bu araştırmadan elde edilen bulguların sınanması, araştırmanın niteliğini arttıracağı düşünülmektedir. Ayrıca GME yaklaşımının öğrencilerin akademik başarılarını, problem çözmeye yönelik tutumlarını ve görsel matematik okuryazarlıklarını arttırdığı sonuçlarına ulaşıldığından bu yaklaşımın kullanımına uygun konularda derslerin planlanması önerilmektedir. GME yaklaşımının etkilediği diğer değişkenlerin de belirlenmesi önemli görülmektedir. 
Araştırmanın deney grubuyla yapılan görüşmelerden elde edilen nitel bulgular incelendiğinde, öğrencilerin GME’ye uygun sınıf ortamını beğendikleri görülmüştür. Özellikle sınıfın " $U$ ” şeklinde olması, gruplara ayrılması, sınıf içinde çeşitli materyallerin kullanılması öğrencileri derse daha çok motive ettiği söylenebilir. Bu sonuçlara destek olarak, Fauzan (2002) yaptığı bir araştırmada GME yöntemi ile ders işleyen öğrencilerin bu yaklaşımı beğendikleri sonucuna ulaşmıştır (akt. Çilingir, 2015).

Araştırmadaki etkinliklerin çeşitliliği, her öğrenciye hitap edilebilecek düzeyde ve her öğrencinin ilgisini çekebilecek nitelikte olması öğrencilerin heyecanlamasını ve dersten zevk almasını sağlamıştır. Çakır’ın (2013) yaptığı çalışmada GME yaklaşımı kullanılarak öğretim süresince öğrencilerin GME’yi zevkli buldukları, etkinliklere severek katıldıkları; problem durumları çözerken kullandıkları stratejileri daha iyi açıkladıkları, tartıştıkları ve bunu yaparken de birbirleriyle daha iyi etkileşimde bulundukları sonuçlarına varılmıştır.

Yapılan araştırmada etkinlikler daha çok görsellik üzerine kurulmuştur ve öğrencilere yöneltilen görsel problemleri mi yoksa sözel problemleri mi tercih ettikleri sorunda öğrencilerin çoğu görsel problemleri tercih ettikleri çünkü görsel problemleri daha kolay ve daha iyi anladıklarını belirtmişlerdir. Bu sonuç, Duran’ın (2011) yüksek lisans tezinde, öğrencilerin görsel olarak verilen bir problemi daha iyi anladıklarını belirtmeleriyle örtüşmektedir.

Bu çalışmadan elde edilen bulgular çerçevesinde aşağıdaki öneriler üzerine gelecek çalışmalar yapılabilir:

- Farklı ünitelerde veya farklı sınıf düeylerinde GME yaklaşımının öğrenci başarısına etkisi incelenebilir.

- Öğrencilerin görsel matematik okuryazarlığı algıları üzerine nelerin etki edebileceği araştırılabilir.

- Görsel matematik okuryazarlığının problem çözme süreçlerinin hangi aşamalarında ortaya çıktığı ve bunu geliştirmek adına nasıl stratejilerin geliştirilmesiyle ilgili çalışmalar yapilabilir. 


\section{Kaynaklar}

Altun, M., (2002). Sayı doğrusunun öğretiminde yeni bir yaklaşım, İlköğretim- Online, 1(2).

Avrupa Komisyonu. (2011). Avrupa'da Matematik Eğitimi. http://eacea.ec.europa.eu/education/eurydice/ documents/thematic_reports/132TR.pdf sitesinden 23.05.2014 tarihinde alınmıştır.

Can, M. (2012). İlköğretim 3. Sinıfta ölçme konusunda gerçekçi matematik eğitimi yaklaşımının öğrenci başarısına ve kalıcılığa etkisi. Yayınlanmamış Yüksek Lisans Tezi, Abant İzzet Baysal Üniversitesi, Eğitim Bilimleri Enstitüsü: Bolu

Creswell, J. W. (2013). Araştırma deseni. Çev. Selçuk Beşir Demir (Ed.)). İstanbul: Eğiten Kitap.

Çakır, P. (2013). Gerçekçi matematik eğitimi yaklaşımının ilköğretim 4. sını öğrencilerinin erişilerine ve motivasyonlarına etkisi. Yayınlanmamış Yüksek Lisans Tezi, Dokuz Eylül Üniversitesi, İzmir.

Çilingir, E. (2015). Gerçekçi matematik eğitimi yaklaşımının ilkokul öğrencilerinin görsel matematik okuryazarlı̆̆ düzeyine ve problem çözme becerilerine etkisi. Yayınlanmamış Yüksek Lisans Tezi, Çukurova Üniversitesi, Adana.

De Corte, E., (2004). Mainstreams and perspectives in research on learning (mathematics) from instruction, Applied Psychology: An International Review, 53 (2), 279-310.

Duran, M. (2016). İlköğretim 7. sınıf öğrencilerinin görsel matematik okuryazarlığı hakkındaki görüşleri. Mehmet Akif Ersoy Üniversitesi Eğitim Bilimleri Enstitüsü Dergisi, 2 (2), 38-51.

Duran, M. (2011). İlköğretim 7.sını öğrencilerinin görsel matematik okuryazarlı̆ğ özyeterlik algıları ile görsel matematik başarıları arasındaki ilişki. Yayınlanmamış Yüksek Lisans Tezi, Erzincan Üniversitesi, Erzincan.

Duran, M. ve Bekdemir, M. (2013). Görsel matematik okuryazarlığı özyeterlik algısıyla görsel matematik başarısının değerlendirilmesi. Pegem Eğitim ve Öğretim Dergisi, 3(3), 27-40.

Eisenberg, T. \& Dreyfus, T. (1990). On the reluctance to visualize in mathematics. In W. Zimmerman \& S. Cunningham (Eds.), Visualization in teaching and learning mathematics, MAA Notes 19, 25-37, Washington, DC: Mathematical Association of America.

Freudenthal, H. (1973). Mathematics as an educational task. Dordrecht: Reidel.

Gutiérrez, A. (1996). "Visualization in 3-dimensional geometry: In search of a framework," in L. Puig and A. Guttierez (eds.) Proceedings of the 20th conference of the international group for the psychology of mathematics education, 1, 3-19. Valencia: Universidad de Valencia.

İşler, A. Ş. (2002). Günümüzde Görsel Okuryazarlık Ve Görsel Okuryazarlık Eğitimi. Uludağ Üniversitesi Eğitim Fakültesi Dergisi, 15(1), 153-161.

Keijzer, R. (2003). Teaching formal mathematics in primary education. Utrecht: CD-Beta Press.

Keller, J.J., (1990). Stategy games: Developing positive attitudes and perseverance toward problem solving with fourth graders. (ERIC document Number:ED323013) http://searcheric.org/scripts/seget2. asp?db=ericdb\&want=http://searcheric.org/ericdb/ED323013.htm accessed July 302013.

M.E.B. (2009b). İlköğretim matematik programı giriş bölümü. Ankara: M.E.B. Yayınevi

National Council of Teachers of Mathematics. [NCTM]. (1989). Curriculum and evaluation standarts for school mathematics. Reston: NCTM Publications

Patton, M. Q. (2014). Nitel araştırma ve değerlendirme yöntemleri. Çeviri Editörleri: Mesut Bütün ve Selçuk Beşir Demir), Ankara: Pegem Akademi.

Rival, I. (1987). Picture puzzling: Mathematicians are rediscovering the power of pictorial reasoning, The .Sciences, 19, 41-46

Sitorus, J. (2016). Students' creative thinking process stages: Implementation of realistic mathematics education. Thinking Skills and Creativity, 22, 111-120. 
Tavşancıl, E. (2006). Tutumların ölçülmesi ve SPSS ile veri analizi. Ankara: Nobel Yayın Dağıtım.

Treffers, A. (1978). Wiskobas doelgericht [Wiskobas goal-directed]. Utrecht: IOWO.

Treffers, A. (2012). Three dimensions: A model of goal and theory description in mathematics instructionThe Wiskobas Project (Vol. 3). Springer Science \& Business Media.

Tunalı, Ö. (2010). Açı kavramının gerçekçi matematik öğretimi ve yapılandırmacı kurama göre öğretiminin karşılaştırılması. Yayınlanmamış Yüksek Lisans Tezi, Uludağ Üniversitesi Sosyal Bilimler Enstitüsü: Bursa

Ünal, Z. A. ve İpek, A. S. (2009). Gerçekçi Matematik Eğitiminin İlköğretim 7.sınıf öğrencilerinin tam sayılarla çarpma konusundaki başarılarına etkisi. Eğitim ve Bilim, 34 (152), 60-70.

Van den Heuvel-Panhuizen, M. (2000). Mathematics education in the Netherlands: A guided tour. Freudenthal Institute Cd-rom for ICME9. Utrecht: Utrecht University

Van Den Heuvel-Panhuizen, M. (2003). The didactical use of models in Realistic Mathematics Education:an example from a longitudinal on percentage. Educational Studies in Mathematics, 54(1), 9-35.

Verschaffel, L., De Corte, E., Lasure, S., Van Vaerenbergh, G., Boagerts, H., \& Ratincky, E. (1999). Learning to solve mathematical application problems: A design experiment with fifth graders. Mathematical Thinking \& Learning, 1(3), 195-229.

Verschaffel, L. and De Corte, E., (1997). Teaching realistic mathematical modeling in the elementary school: a teaching experiment with fifth graders, Journal for Research in Mathematics Education, Vol.: 28, 577-601. 
